\title{
Udviklingsbistanden og udenrigspolitikken
}

Af Lars Engberg-Pedersen

Argumentet i denne artikel er, at til trods for klare politiske intentioner om det modsatte og til trods for de mange penge, der bliver anvendt i Danmarks udviklingssamarbejde, er udvilklingsbistanden aldrig rigtigt blevet set som et centralt instrument $i$ udenrigspolitikken. Det kommer dog noget an på, hvordan man definerer udenrigspolitikken, og udenrigspolitikkens indflydelse skifter også over tid.

Hvis ovenstående pointe holder, hvilket jeg vil forsøge at argumentere for i det følgende, kan man spørge, om den er væsentlig. Det er den efter min mening, fordi fattige lande er 'rykket tættere’ på Danmark. Hvad der sker på den anden side af kloden, får stadig større betydning for Danmark, og udenrigspolitikken bør derfor integrere dette perspektiv. Ikke desto mindre er der en historisk betinget tendens til at betragte udviklings- og udenrigspolitik som to adskilte siloer.

En alternativ fortolkning af udviklingen er, at udviklingsbistanden over årene er blevet stadig mere integreret i udenrigspolitikken, men på en
5

\author{
Værdipolitiske elementer i \\ udenrigspolitikken hører under \\ 'nice to have' og har ofte inden- \\ rigspolitiske målgrupper frem for \\ egentlige målsætninger om at \\ ændre andre lande.
}

måde der fokuserer på kortsigtede interesser og sætter bistandens komparative fordele over styr. I det perspektiv kan man sige, at bistandsmidlerne anvendes ineffektivt inden for udenrigspolitikken.

\section{Hvad er udenrigspolitik?}

Det kan forstås på flere måder: Centralt er det at sikre statens stabilitet, indflydelse og handlefrihed, hvorfor sikkerhedspolitik er alfa og omega. Fremme af økonomiske interesser og kommercielle relationer til andre lande er også vigtigt, og udbredelsen af værdier karakteristiske for det danske samfund nævnes til tider som en del af udenrigspolitikken, men der er næppe tvivl om, at disse tre emner prioriteres i den nævnte rækkefølge. Værdipolitiske elementer i udenrigspolitikken hører under 'nice to have' og har ofte 
indenrigspolitiske målgrupper frem for egentlige målsætninger om at ændre andre lande.

Væsentligt er det at sondre mellem det korte og det lange sigt i udenrigspolitikken, selv om de selvfølgelig kan overlappe. Alliancer og internationale spilleregler er en særlig langsigtet interesse for et lille land som Danmark, der har glæde af stabilitet, forudsigelighed og en vis begrænsning af større og mere magtfulde landes uhindrede varetagelse af egne interesser. Derfor er de nuværende tendenser i retning af at undergrave et regelbaseret internationalt samarbejde også særligt bekymrende for Danmark.

Kortsigtede interesser handler om umiddelbare udfordringer, og de kan på ingen måde tilsidesættes, fordi de kan forhindre eller udfordre realiseringen af de langsigtede interesser. Omvendt skal de dog heller ikke komme til at spille så stor en rolle, at det langsigtede perspektiv forsvinder.

Antallet af brændpunkter med betydning for Danmarks sikkerhedspolitiske og økonomiske interesser har været stigende de senere år. Rusland opfattes nu som en betydelig militær og elektronisk trussel, terrortruslen fra religiøse ekstremister har været markant de seneste godt 15 år, 'flygtningekrisen' udfordrer med ret eller uret stabiliteten i Europa og Danmark, og Brexit forrykker balancen i EU og risikerer at skade samhandlen med England.

Udenrigspolitikken har således nok at forholde sig til på den korte bane, men det bør ikke undergrave det langsigtede perspektiv. Man kan imidlertid være bekymret for, at der i øjeblikket er tendenser i den retning, og at fregatten Danmark sejler uden at vide til hvilken havn.

En anden sondring, der jævnligt foretages i udenrigspolitikken, er mellem områder tæt på Danmark og lande og udfordringer længere væk. Arktis, Østersøen og EU er selvsagt af betydelig interesse, fordi initiativer og forandringer dér ofte vil have umiddelbare konsekvenser for Danmark. Uenigheden opstår, når man som Peter Taksøe-Jensen i sin udenrigs- og sikkerhedspolitiske rapport til statsministeren i maj 2016 foreslår, at Danmark skal koncentrere sig mere om 'nærområderne' og nedprioritere engagementet $i$ andre verdensdele.

I en stadig mere globaliseret verden er det svært at se geografisk afstand som den nødvendigvis mest betydningsfulde faktor for udenrigspolitikken. Kommercielle risici, ideologiske udfordringer, sikkerhedstrusler og menneskestrømme kan lige så vel udspringe i forhold på den anden side af kloden.

Samtidig virker det lidet overbevisende, at Danmarks langsigtede interesser i internationale spilleregler og alliancer, der skaber stabilitet, kan realiseres gennem en udenrigspolitik, der er afgrænset til en del af kloden. Det forekommer at være et perspektiv, der var mere velegnet til en verden anno 1950.

\footnotetext{
I en stadig mere globaliseret verden er det svært at se geografisk afstand som den nødvendigvis mest betydningsfulde faktor for udenrigspolitikken.
} 
I udviklingsbistandens første år var målsætningen at bidrage til fattige landes økonomiske vækst, sociale fremgang og politiske uafhængighed. rettigheder spillede ingen central rolle, mens man i stedet forsøgte at overføre danske
På den baggrund vender jeg mig mod udviklingsbistandens historiske udvikling, som kan deles op i tre perioder, og diskuterer den ud fra et udenrigspolitisk perspektiv.

\section{2-1989}

I udviklingsbistandens første år var målsætningen at bidrage til fattige landes økonomiske vækst, sociale fremgang og politiske uafhængighed.

Det sidste var vigtigt og en naturlig følge af afkoloniseringen, og det betød, at der blev gjort meget få forsøg på at påvirke modtagerlandenes politikker i denne periode. Værdier som demokrati, ligestilling og menneske- teknologier og udviklingsmodeller som andelsbevægelsen.

Det kan selvfølgelig ses som et forsøg på at præge fattige lande i retning af 'den danske model', men var i højere grad udtryk for manglende opfindsomhed. Man anvendte de løsninger, som havde virket i Danmark, og det afstedkom i nogle tilfælde 'hvide elefanter' - fabrikker, infrastruktur og andre investeringer, som var ganske utilpassede til de lokale forhold og derfor forfaldt i samme øjeblik, de var overdraget til modtagerne.

De fire store modtagerlande i denne periode - Indien, Bangladesh, Kenya og Tanzania - var valgt af historiske

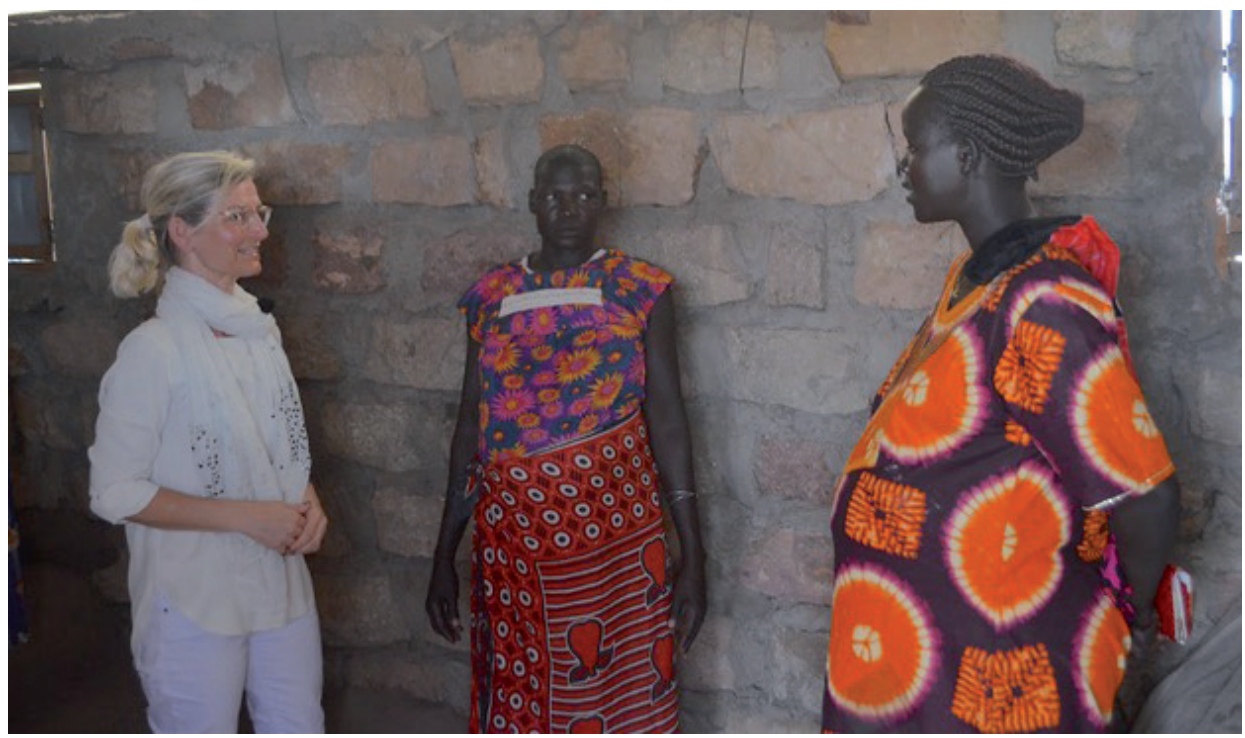

FOTO: Kenya Red Cross

Minister for udviklingssamarbejde Ulla Tørnæs besøger Kenyansk Røde Kors' sundhedsklinik i Kalobeyei flygtningelejr 6. marts 2018 
Mens store lande og tidligere kolonimagter anvendte udviklingsbistanden med klare geopolitiske formål og i den kolde krigs opgør med kommunismen, gjaldt det kun i begrænset omfang de skandinaviske lande. rigspolitiske referencer spøgte i baggrunden (Bach, Christian Friis, Thorsten Borring Olesen, Sune Kaur-Pedersen og Jan Pedersen: Idealer og realiteter: Dansk udviklings- årsager snarere end ud fra udenrigspolitiske overvejelser. De figurerede på ingen måde i sikkerheds- eller handelspolitiske prioriteringer, men var fattige, engelsktalende lande, med hvem der var visse historiske bånd.

Noget der dog - jævnfør diskussionen ovenfor - var et udenrigspolitisk hensyn, var den vægt, der blev lagt på 'returprocenten'. Returprocenten udtrykte den andel af den samlede udviklingsbistand, der kom tilbage til danske virksomheder i form af kontrakter. Der var generelt politisk enighed om, at udviklingsbistanden skulle gavne danske virksomheder og skabe danske arbejdspladser, og det var ganske på linje med, hvordan udviklingssamarbejdet var organiseret $\mathrm{i}$ sammenlignelige lande. Det var imidlertid også én af årsagerne til de 'hvide elefanter', fordi konkurrencen om at opnå kontrakterne var overskuelig.

Mens store lande og tidligere kolonimagter anvendte udviklingsbistanden med klare geopolitiske formål og i den kolde krigs opgør med kommunismen, gjaldt det kun i begrænset omfang de skandinaviske lande. For dem var det vigtigt at bidrage til afkoloniseringen og udvise solidaritet med fattige lande.

Ikke desto mindre viser en debat mellem Jørgen Junior, Fremskridtspartiet, og Uffe Ellemann-Jensen, Venstre, i Folketinget i 1978, at uden- politiks historie 1945-2005, Gyldendal 2008).

Jørgen Junior kritiserede, at udviklingsbistanden brugtes på 'at fremme marxistiske bevægelser', der kunne finde på at vende sig mod os selv, mens Uffe Ellemann-Jensen talte om den rige og den fattige mand, hvor den sidste tabte tålmodigheden med den første og slog ham ihjel.

Grundlæggende var afstanden mellem Danmark og udviklingslandene, som de fattige lande blev betegnet i denne periode, dog så stor på alle parametre, at de ikke truede eller påvirkede danske interesser på nævneværdig måde. Dansk udenrigspolitik kunne trygt koncentrere sig om østvest konflikten og Europas udvikling i disse år, og det var sikkert en medvirkende årsag til, at udviklings- og udenrigspolitikken udviklede sig i forskellige retninger.

\section{9-2001}

Op gennem 1980'erne begyndte man så småt at tænke i mere præcise mål for udviklingssamarbejdet, og en handlingsplan fra 1988 omtaler bæredygtig udvikling, menneskerettigheder og ligestilling som vigtige temaer. Med Berlin-murens fald og 'historiens endeligt' begyndte en ny epoke i det internationale udviklingssamarbejde, hvor der var et mindre geopolitisk behov for at 'købe' støtte i Syd, men 
Den voksende ambition om at påvirke fattige landes udvikling inden for brede rammer afspejlede en vilje til at presse danske værdier igennem, og den multilaterale aktivisme havde $i$ et vist omfang til formål at tilgodese danske interesser. i høj grad også til at øge organisationernes effektivitet.

Baggrunden var en debat, hvor Venstre med flere ønskede at til gengæld en mere udbredt opfattelse af at udvikling var lig en vestlig samfundsmodel.

Den første egentlige danske udviklingsstrategi fra 1994 fastslog fattigdomsbekæmpelse som den overordnede målsætning og de tre ovennævnte størrelser som tværgående hensyn. Strategien understregede samtidig, at dansk udviklingssamarbejde baserer sig på et partnerskab, hvor modtagerne har stor indflydelse på aktiviteterne for at sikre deres relevans.

Første halvdel af 1990'erne var en markant periode, hvor bistanden voksede til én pct. af bruttonationalindkomsten (BNI), og hvor man begyndte en omlægning af bistanden fra projekter til programmer, der typisk omfattede en hel sektor. Tanken var, at de institutionelle rammer såvel nationalt som lokalt skulle styrkes, hvis man ville forbedre sektorer som landbrug, uddannelse, sundhed osv. I denne periode var der således stort fokus på sektorspecialister, og udviklingssamarbejdet blev stadig mere professionaliseret.

Begrebet 'aktiv multilateralisme' dukkede også op på dette tidspunkt. Pointen var at bruge de midler, der kanaliseredes gennem de multilaterale organisationer, til at fremme de nævnte mål og hensyn i FN-systemet og over for udviklingsbankerne, men øge den bilaterale bistand på bekostning af den multilaterale, fordi førstnævnte gav flere arbejdspladser i Danmark. Den multilaterale bistand skulle derfor tjene danske interesser mere eksplicit.

Det kan opfattes som det tredje og mindst prioriterede element i udenrigspolitik. Den voksende ambition om at påvirke fattige landes udvikling inden for brede rammer afspejlede en vilje til at presse danske værdier igennem, og den multilaterale aktivisme havde i et vist omfang til formål at tilgodese danske interesser.

Ikke desto mindre handlede professionaliseringen nok så meget om de herskende ideer om fattigdomsbekæmpelse. Mange afrikanske lande fik demokratiske grundlove i første halvdel af 1990'erne, og efter det tabte årti i 1980'erne, hvor den økonomiske vækst var gået uden om Afrika, var der både muligheder og behov for fremgang. Internationalt bredte der sig en forestilling om, at demokrati og menneskerettigheder var forudsætninger for vækst, og institutionel udvikling blev et nøglebegreb. Disse ideer prægede i høj grad dansk udviklingssamarbejde.

Den aktive multilateralisme, der kunne have sigtet på at styrke det multilaterale system og præge det med danske værdier, handlede hovedsageligt om at få $\mathrm{FN}$-organisationer til 
København og danskere på internationale lederposter. Det er også udenrigspolitik, men ikke af den langsigtede slags møntet på at skabe stærke internationale regler og multilaterale organisationer. I bund og grund var der tale om det traditionelle ønske om at skabe danske arbejdspladser ved hjælp af udviklingsbistanden.

I slutningen af 1990'erne begyndte sikkerhedspolitikken at blive mere orienteret mod konflikter i Syd. Den umiddelbare anledning var krigen på Balkan og det danske engagement i Kosovo. En forsvarskommission barslede i 1998 med en rapport, der pegede på fx flygtninge, kriminalitet og statsterrorisme som konsekvenser af konflikter.

\section{1-}

11. september-angrebet på USA og regeringsskiftet i Danmark forstærkede kraftigt sammenblandingen af sikkerheds- og udviklingspolitik.

Irak og Afghanistan kom i centrum for international udviklingsbistand, og Afghanistan blev også et af de største modtagerlande for dansk bistand. Stabilitet og udvikling sås som hinandens forudsætninger, og 'winning hearts and minds' blev et argument for at lade udviklingsbistanden følge de militære indsatser selv i områder, hvor det var umuligt for civilister at færdes.

Bistandsindsatsen i Afghanistan blev dog også kraftigt kritiseret, dels fordi den var en del af den meget store internationale støtte, der oversteg, hvad landet kunne absorbere, og delvist derfor stimulerede en omfattende korruption, dels fordi bistand til konfliktzoner med tilstedeværelse af danske soldater i et vist omfang lod til at stimulere konflikten.

Politisk blev bekæmpelse af terrorisme og radikalisering argumenter for at kanalisere bistanden til nye områder som fx i Pakistan, og udviklingspolitikken flyttede til dels fokus fra relativt stabile fattige lande til såkaldt skrøbelige situationer som Afghanistan, Somalia, Sydsudan og efterhånden Mali.

2001 markerer også et skift i regeringsmagten, der afstedkom den første massive nedskæring af dansk udviklingsbistand overhovedet. Fra at have vokset støt siden undfangelsen i 1962 og efter at have ligget på omkring én pct.af BNI igennem det meste af 1990'erne blev den beskåret til ca. 0,85 pct. Et antal landeprogrammer blev lukket, og støtten til danske civilsamfundsorganisationer blev reduceret. Så vigtig for sikkerhedspolitikken var udviklingsbistanden alligevel heller ikke.

En anden udenrigspolitisk påvirkning af udviklingssamarbejdet var Per Stig Møllers Det Arabiske Initiativ oprettet i 2003. Tanken var at stimulere dialog og samarbejde mellem Mellemøsten og Danmark, fremme demokrati og menneskerettigheder, støtte reformprocesser, skabe arbejdspladser og fremme kvinders rolle i samfundslivet i både Mellemøsten og Nordafrika. Det skulle ikke mindst ske gennem et samarbejde mellem danske og mellemøstlige civilsamfundsorganisationer.

Bortset fra en mangeårig støtte til palæstinenserne på Vestbredden og i Gaza havde Mellemøsten og Nordafrika glimret ved sit fravær i dansk 
Det korte af det lange er, at hvis udviklingsbistanden var blevet opfattet som en central komponent i udenrigspolitikken, ville det næppe være politisk bæredygtigt at gennemføre så omfattende beskæringer og omallokeringer. udenrigspolitikken, annoncerede Venstre, at når de overtog regeringsmagten efter et valg, ville de beskære udviklingsbistanden til 0,7 pct. fra de ca. 0,85 pct. udviklingssamarbejde. Det var sådan set forståeligt nok, idet landene i regionen ikke tilhører de fattigste. $\mathrm{Nu}$ var tanken imidlertid at anvende egentlig langsigtet udviklingssamarbejde ikke bare for at fremme de gængse udviklingsmålsætninger, men i allerhøjeste grad også for at skabe bedre relationer mellem Danmark og de involverede lande. Den udenrigspolitiske interesse i stabilitet og dialog var umiskendelig og blev kun yderligere understreget af 'tegningekrisen' i 2006.

I 2010 blev Søren Pind udviklingsminister og udarbejdede straks en 'frihedsstrategi' for udviklingssamarbejdet. Hans aftryk var dog hovedsageligt ideologisk, da strategien ikke markerede noget brud med den hidtidige politik. Det skete i højere grad under Christian Friis Bach, som ikke alene fremmede en rettighedsbaseret tilgang i sin strategi fra 2012, men også var en del af en regering med en handelsminister. Erhvervslivets rolle i udviklingssamarbejdet voksede parallelt med de vinde, der blæste internationalt. Snart efter lancerede udenrigs-, forsvars- og justitsministerierne en politik for samtænkning af indsatser i skrøbelige områder, hvor forbindelsen mellem sikkerheds- og udviklingsaktiviteter blev understreget.

Samtidig med disse udviklinger, som kunne antyde, at udviklingssamarbejdet var ved at få en central rolle i af BNI under den socialdemokratisk ledede regering. Som sagt så gjort efter valget i juni 2015.

Samtidig var antallet af asylans $\varnothing-$ gere begyndt at vokse kraftigt, og da visse udgifter i den sammenhæng kan opgøres som udviklingsbistand i henhold til OECD's regler, blev budgettet for den bilaterale bistand beskåret med 50 pct. over en periode på 15 måneder (Engberg-Pedersen, Lars og Adam Moe Fejerskov: 'The transformation of Danish foreign aid', i Kristian Fischer og Hans Mouritzen (eds.): Danish foreign policy review 2018, DIIS)

I budgettet for 2016 var 30 pct. af udviklingsbistanden sat af til modtagelse af asylansøgere i Danmark, og i finanslovsaftalen blev Venstre og støttepartierne, Dansk Folkeparti, Liberal Alliance og de Konservative, enige om, at skulle der komme flere asylansøgere end forventet, så skulle de ekstra udgifter også dækkes af udviklingsbistanden.

Det korte af det lange er, at hvis udviklingsbistanden var blevet opfattet som en central komponent i udenrigspolitikken, ville det næppe være politisk bæredygtigt at gennemføre så omfattende beskæringer og omallokeringer. Som antydet i starten af artiklen er de udenrigspolitiske udfordringer ikke just for nedadgående, men da udviklingssamarbejdet ikke betragtes 
som en løsning på dem, kan det roligt skæres ned.

Den seneste udviklingspolitiske strategi fra januar 2017 er vedtaget af alle partier i folketinget bortset fra Enhedslisten. Den har fire prioriteter, som sat på spidsen handler om:

1) at støtte nærområder til konflikter, således at flygtninge bliver i disse områder,

2) at begrænse migration,

3) at stimulere danske virksomheders rolle i udviklingssamarbejdet,

4) at fremme menneskerettigheder, demokrati og ligestilling.

\section{$\square$ Ligeledes er udviklingsbistanden siden anden halvdel af 1980'erne blevet brugt til at søge at fremme bestemte værdier så som demokrati, menneskerettigheder og ligestilling.}

Hvis man opfatter indvandring som destabiliserende, kan strategien siges at være stærkt præget af et udenrigspolitisk ønske om at undgå flygtninge og migranter, men strategiens to første prioriteter kan også læses som et forsøg på at bruge udviklingsbistanden til indenrigspolitisk signalpolitik.

Det ville være i fin forlængelse af Søren Pinds begejstring for frihed og af andre markeringer, som ikke nødvendigvis har taget udgangspunkt i fattige landes centrale udfordringer. Sammenlignet med tidligere strategier er det også markant, så klart interessen $i$ at stimulere dansk økonomi fremgår af den tredje prioritet. Endelig er de traditionelle udviklingspolitiske målsætninger henvist til den fjerde prioritet.

\section{Bistand og udenrigspolitik}

Den her gennemgang af udviklingsbistanden med udenrigspolitiske briller er ambivalent. På den ene side er det tydeligt, at udviklingsbistanden i større eller mindre grad altid har haft andre målsætninger end fattigdomsbekæmpelse og dertil hørende undermål. Klarest over tid er ønsket om at bruge bistanden til at skabe arbejdspladser i Danmark og støtte dansk erhvervsliv. I anden halvdel af 1990'erne og gennem 00'erne var denne interesse ikke så stærkt formuleret, så den er ikke naturnødvendig, men ellers har den været gennemgående.

Siden slutningen af 1990'erne er udviklingssamarbejdet blevet knyttet stærkere til sikkerhedspolitikken, og det bånd er blevet styrket af en politisk interesse $i$ at bekæmpe terrorisme og radikalisering. Støtten til Somalia er desuden motiveret af at forhindre pirateri og sikre danske rederier åbne sejlruter. På det seneste er opmærksomheden rettet mod at forhindre flygtninge og migranter $i$ at nå frem til Danmark, og det er så tanken, at udviklingsbistanden er anvendelig her.

Ligeledes er udviklingsbistanden siden anden halvdel af 1980'erne blevet brugt til at søge at fremme bestemte værdier så som demokrati, menneskerettigheder og ligestilling. Det har dog i nok så høj grad været som en del af den internationalt herskende forståelse af, hvad udvikling er, og hvordan den skabes, som det har været udtryk for en udenrigspolitisk interesse $i$ at sprede danske synspunkter.

De skiftende målsætninger for udviklingssamarbejdet kan hovedsageligt kaldes udenrigspolitiske i det omfang, 


\section{Brugen af udviklingsbistanden til} skiftende kortsigtede udenrigspolitiske mål er dels ineffektiv, dels undergravende for bistandens egentlige udenrigspolitiske bidrag.

at de har til formål at sikre statens stabilitet og handlefrihed og fremme dansk økonomi. Det er i et vist omfang tilfældet, men målsætningerne har, bortset fra hensynet til dansk økonomi, næsten altid været kortsigtede: En udenrigspolitisk udfordring opstår, og så sætter man udviklingsbistanden til at løse den i mangel af bedre.

På den anden side er der næppe tvivl om, at udviklingssamarbejdet og udenrigspolitikken er blevet opfattet som hver sin silo til tider understøttet af hver sin minister. De mange bistandsmidler har krævet en professionalisering og fokusering, som har trukket eksperter, diskurser, modeller og praksisser med sig, og samtidig har civilsamfundsorganisationer presset på for at gøre fattigdomsbekæmpelse til den overordnede målsætning. Omvendt har udenrigspolitikken $i$ langt højere grad været orienteret mod realpolitisk interessevaretagelse hovedsageligt i den vestlige verden.

De senere års nedskæringer af udviklingsbistanden vidner også om, at de to emnefelter ikke er særlig godt integreret. Det forekommer i hvert fald overraskende at foretage dramatiske nedskæringer på et felt, hvis man opfatter det som et væsentligt bidrag til at sikre statens stabilitet og handlefrihed i en verden, hvor antallet af globale kriser er voksende, hvor magt- balancen i stigende omfang er uafklaret, hvor traditionelle institutioner for internationalt samarbejde udfordres, og hvor uforudsigeligheden generelt er voksende.

Brugen af udviklingsbistanden til skiftende kortsigtede udenrigspolitiske mål er dels ineffektiv, dels undergravende for bistandens egentlige udenrigspolitiske bidrag.

Ineffektiviteten går på, at udviklingsbistand kun har langsigtede effekter. Den kan ikke bruges mod terrortrusler, radikalisering, konflikter, indvandring med videre på kort sigt. Bistanden bidrager med at skabe forudsætninger for fremgang, men den skaber ikke i sig selv sociale forandringer og udvikling på den korte bane. Derfor er den ikke et hensigtsmæssigt instrument i forhold til udenrigspolitiske brændpunkter.

Når bistanden anvendes dér, undergraver det samtidig dens langsigtede bidrag til udenrigspolitikken. Alverdens ledere vedtog i 2015 de såkaldte verdensmål, der skal indfries i 2030 . Disse 17 mål er ambitiøse og vil bidrage til en mere forudsigelig, stabil og fremgangsrig verden, og målene er samtidig et fint udtryk for den nordiske velfærdsmodel.

Ikke alene vil en markant investering i disse mål gøre verden mere 'nordisk', den vil også skubbe verden i en retning, der sikrer den danske stats stabilitet og handlefrihed og alle danskeres velfærd i fremtiden. Og det ville være en udenrigspolitik med et klart langsigtet mål.

000 